\title{
JUSTICE FOR THE RICH, JUDGEMENT FOR THE POOR: 'ELITE IMMUNITY', RAMPANT IMPUNITY AND THE ADMINISTRATION OF CRIMINAL JUSTICE IN NIGERIA
}

\section{Mike Opeyemi Omilusi ${ }^{1}$}

\section{Introduction}

The challenge of systematically studying the African power elite and the mode by which it governs has become urgent not only because of the conceptual and theoretical dead-ends to which much of current received wisdom leads, but also because a better understanding of the nature, composition and renewal of the elite is critical to our understanding of the governance of the public sphere (CODESRIA, 2003). A focus on political elites is a focus on the primacy of political interests. As both Mosca and Pareto underscore in their works, members of the elite act in order to preserve their position within their societies. Specifically, political elites' action is aimed at the preservation of their political power. As Thomas Schwartz argues, members of the political elite are 'ambitious people seeking office for individual recognition, career advancement, and the power to affect societies' (Schwartz 2009, cited in Tardelli, 2013:88-89).

While some mature natural states institutionalize relations among elites so that privileges are regularized in a way that they begin to become transformed into rights. Put another way, privileges move from being personal and idiosyncratic to being impersonally applied equally to all elites (Weingast, 2008:7), in some other climes, elites have been regarded as the

I Department of Political Science, Ekiti State University, Nigeria. E-mail:watermike2003@ yahoo.co.uk 
Chief threat to the survival of democracy. Their existence has been taken to be the very denial of democracy. Elites which have exceptional access to key positions in the society or which appear to wield control over critical and crucial policies disproportionate to their numbers can understandably seem to be living contradictions of the notion of government by the people (Duru, 20I2). As pointed out by Gumede (20IO), small group of elites which dominate politics, intellectual capital and business are at the heart of failures of most African countries since independence. As a result of this, minorities have become richer and more entrenched while the poor segments of the African societies have become poorer.

It is in this context that the administration of justice - central to the survival of democratic government - is analysed in this essay in relation to elite immunity and its attendant rampart impunity in Nigeria. It is argued that if the criminal justice system, due to its inbred unaccountability, is unable to efficiently and speedily punish illegal doing, then people will carry out criminal acts with no heed for the consequences. If civil process finds it virtually impossible to enforce commercial contracts, then parties are encouraged to breach them with impunity because there is no certainty of consequences. If institutions, due to their inefficiency, serve the interests of the violator rather than the victim, then impunity is encouraged (Arthur-Worrey, n.d). Put differently, the most common failing in the criminal area is the impunity of well-connected individuals. The privileged may include politicians, elected officials, high ranking military personnel, members of the dominant social class, and wealthy elites.

Given the allegation of corrupt practices against some of these officeholders there have been calls for the removal of the immunity conferred on them by the Nigerian Constitution, so as to make way for their possible prosecution in court while in office. Others have argued for the retention of the immunity provision, otherwise called the immunity clause (Arishe, 20I0:274). It is worrisome that public officials abuse these privileges with high sense of impunity. This often goes without any form of punishment to serve as deterrent to other potential offenders. It often precipitates more abuse in the polity. Yet, while the Nigerian courts mockingly and seemingly ruthlessly deal with the poor, the rich are patronisingly pampered and most times, evade justice. Though the Nigerian constitution guarantees justice and equality for all citizens, a lot of people, especially the poor and vulnerable, are still unable to get access to justice in the country. While the poor get rotten in prison for years while awaiting trial, soft landing mechanism is devised for the rich - just to return looted money and go home. This study therefore, interrogates the content and context of executive immunity and 
its attendant culture of impunity that permeates the political environment. It contends that the immunity clause not only sanctifies, abinitio, criminal behavior by the said public officials but also gives them every incentive to be vile and depraved to their heart's content - to turn immunity into impunity.

\section{Governance, Corruption and Enforcement of Law: The Socio-Political Ecology of the Nigerian Society}

A social problem connotes an act or a form of behaviour which constitutes concern to a significant proportion of the society to warrant a common solution by that society. The structural-functionalists regard social problems as serious behavioural deviations hindering the functioning of society; social problems are regarded as inhibiting the needs and goals of society. The sociological perspective does not regard a particular form of behaviour as the problem of the individual, but regards the individual behaviour as emanating from the social order in which the individual lives. This agrees with the Durkheimian postulation that all behavior is socially generated.

There is a growing academic literature on the nature and character of the socio-political ecology that germinates the degree or variant of corruption that exists in a particular society, and how other factors combine to nurture it. Its (corruption's) root, given experiences, can be found deep and has often been rightly located, in the unavoidable interplays of bureaucratic, corporate and political institutions and/or within the institutions as independent entities. With reference to Nigeria, corruption has almost become a culture; a situation which has negatively impacted heavily, not only on the country's development, but even on its image. Indeed, it has retarded its development to such an alarming point that the vast majority of the populace now live in abject poverty, having serially lost their commonwealth to a deeply connected and entrenched band of thieving elite. Little wonder, corruption has assumed the most topical issue of discourses on governance in Nigeria today. Corruption is so pervasive in the country that it has turned public service into a kind of criminal enterprise. Graft has fueled political violence, denied millions of Nigerians access to even the most basic health and education services, and reinforced police abuses and other widespread patterns of human rights violations.

It is common knowledge that corruption thrives in an environment where the corrupt practices are undertaken by the political leadership at the highest levels of government. In such a situation, two major fallouts are noted. 
First, the corrupt practices of the leaders 'pollute' the morality of the citizens as the latter emulate the negative corrupt practices of the former. Secondly, and most detrimental to the development of the country, is the reluctance of the political leadership which forms the major culprits to aggressively and whole-heartedly prosecute the laws on corruption where they exist. The latter fallout can be appreciated by the fact that a thief does not do a good job when he doubles as a security guard (Ogbodo, 2011:134).

From the political perspective, political systems in many developing countries are increasingly influenced by some form of bribery and corruption which undermine the capacity of the State to make the right policy choices, and to provide overall good governance. From the social perspective, at all levels of society, an increasing number of people are being forced to adapt to new contexts in which corruption of some sort is part of a new way of life, whether they like it or not.

Too often, otherwise honest people are forced to resort to corrupt means to carry on with their daily lives. This creates the ethical dilemma of forced coexistence with individuals and groups who operate on the basis of different moral standards and expect all those with whom they interact to adopt their lifestyle; this can cause insecurity and instability to social systems that weak States can least afford. From the human security perspective, as corruption creates parallel and competing agendas and subverts the rule of law, an increasing number of people are faced with a daily struggle for personal physical security that governments are unable, and in some cases, unwilling to guarantee. Perhaps the worst-case scenario is when the government is captured by a crime syndicate (Hassan 2004:27).

In Nigeria, years of military dominance in governance created and entrenched the culture of impunity. The military ruled with absolute disregard for the rule of law and so created a national psyche of 'militarization'. This has persisted till date, despite more than a decade of steady democratic governance, where it is expected that public conscience and accountability would drive development. However, the reverse is the case. Impunity has acquired its unique Nigerian meaning (Human Development Initiatives, 20I4). Without doubt, the unpardonable failure of the political leadership class managing the affairs and wealth of the country had inevitably brought severe misery to many voiceless and helpless Nigerians.

It must also be mentioned here that Nigeria's post-independence political bureaucratic and military elites had terribly pillaged the nation's commonwealth and national patrimony with impunity, thereby denying Nigerians access to economic prosperity and quality living condition (Ogbeidi, 
20I2:I8). In other words, the country's picture and identity is replete with confused, factionalized and extremely corrupt elites with a limited sense of nation. These elites lacking strong and viable base in production, turns the state as its primary instrument of primitive accumulation. In the end, the state is mangled and rendered impotent in the quest for nationhood, growth and development, much less democracy (Ihonvbere, I999). As pointed out by Arthur-Worrey, (n.d):

No one wants to live an ordinary, simple life anymore once they are appointed to a high position or have come into money. They have become disruptive influences taking up more public space than they would enjoy in a normal society. They must have numerous aides, they cannot do anything for themselves any longer, and, aping the antics of those in power, they too drive in convoys, as if there weren't enough traffic on our roads and parking spaces, use policemen as drivers and domestics, blare sirens and breach traffic laws, forgetting that they are, by so doing, contributing to the disorder and demeaning the very institutions that are supposed to establish order. And incredibly, the police institution lends itself to this lawless behaviour by providing its officers to all manner of people, even establishing a VIP protection unit with no clear rules or code of conduct for its officers, thereby and perhaps unwittingly, undermining its own authority and making its work of enforcing the law much more difficult.

It is a fact that democratic legitimacy derives from a consensus among citizens and that laws, as administered, represent the collective will. That consensus fades unless laws are applied equally to all persons, regardless of their class, sex, ethnicity, or other characteristics. There cannot be the rule of law without application and enforcement of laws. Even if laws are legitimately derived and equally applied, equality under the law will not occur unless the laws are consistently enforced and applied.

Unequal application of the law regularly occurs in Nigeria especially when the poor and the disadvantaged are victims or the accused. The legal system often does not give such cases the same attention as those cases in which elites are the victims or the accused. In addition, unequal treatment occurs in civil matters, such as land titling, debt collection, taxation, landlord-tenant disputes, mortgage foreclosures, and enforcement of liens and security interests. The poor and disadvantaged often have scant possibility of winning civil cases against the well-connected. The trends and patterns of this development are discussed in the next section. 


\section{The Content and Context of How Immunity Perpetuates Impunity}

By section 5 of the 1999 Constitution, the executive power is conferred on the President at the federal level and on the Governor at the State level. Section 308 provides for the scope of executive immunity as far as Nigeria is concerned:

(I) Notwithstanding anything to the contrary in this constitution, but subject to Subsection (2) of this section:

(a) no civil or criminal proceedings shall be instituted or continued against a person to whom this section applies during his period of office;

(b)a person to whom this section applies shall not be arrested or imprisoned during that period either in pursuance of the process of any court or otherwise; and

(c) no person of any court requiring or compelling the appearance of a person to whom this section applies, shall be applied for or issued;

Provided that in ascertaining whether a period of limitation has expired for the purpose of any proceedings against a person to whom this section applies, noaccount shall be taken of his period of office

(2) the provision of subsection (I) of this section shall not apply to civil proceedings against a person to whom this section in his official capacity or to civil or criminal proceedings in Which such a person is only a nominal party;

(3) this section applies to a person holding the office of president or vice president, governor or deputy governor; and the reference in this section to period of office' is a reference to the period during which the person holding such office is required to perform the functions of the office.

From the above Section, it is evident that the scope of this immunity clause applies to anybody holding the office of President, Vice President, Governors and Deputy Governors for the period of their office, the period of their office is a period within which they hold the office in the respective capacity. It follows that immunity clause will not shield the aforementioned persons who have left office.

The overall effect of Section 308 of the 1999 Constitution is that the elected officers mentioned in Subsection (3) of the section are protected from arrest, prosecution, imprisonment, civil and criminal proceedings while their tenure lasts. And if there has been a case standing against any of them before being elected into office, such a case shall terminate or at least be put 
in abeyance during the continuation of their tenure in office. By section 5 of the I999 Constitution, the executive power is conferred on the President at the Federal level and on the Governor at the State level.

The immunity granted to the officers named in section 308 is personal and not official. It is also an absolute one; one that covers all criminal and civil claims against the beneficiary during his/her tenure in office. The sole justification for immunity is that the heads of state and government should enjoy absolute immunity to enable them to perform official duties without distractions. In other words, such public officers should not be harassed or distracted in the performance of their duties by fear of civil or criminal litigation.

The constitutional practice has always been that the president or governors cannot be prosecuted and even imprisoned while they are still in office and prior to their impeachment. This is logical in law. Immunity of the President and the Governors from criminal proceedings can also be justified on the ground their subjection to the jurisdiction of the courts would be inconsistent with their position as heads of the Executive branch. Because of their unique powers to supervise executive branch and assert executive privilege, the constitutional balance generally should favor the conclusion that a sitting President or Governor may not be subjected to criminal prosecution. This is because the possession of these powers by the President and the Governors renders their prosecution inconsistent with the constitutional structure.

However, the commencement of constitutional amendment by the National Assembly has thrown up a lot of issues of national importance to the court of public opinion. The proposal to give presiding officers of National and State Assemblies immunity and life pension is generating ripples in the polity. According to Falana (20I6):

Apart from the President of our country, the vice president, governors and their deputy, who are protected under immunity in Section 308 of the constitution, others are now insisting that immunity be conferred on them. In particular, the legislators in our country are asking for immunity, but unfortunately, this is not the best time to make that request because right now, some of the leaders of the parliament in our country are standing trial for false declaration of assets, for forgery and conspiracy and some are even under threat of possible deportation to the United States to stand trial for rape and other related offences.

One fundamental reason why lawmakers should not have thought of amending the constitution to give their leaders pension and immunity 
is their refusal to be influenced by the hard facts of the nation's financial crunch. It is no longer news that governments at all levels in the country are facing deep economic and financial crisis as a result of collapsing price of oil and unbridled stealing of public revenue garnered during the years of plenty in the petroleum sector. According to Sekoni (2016:I4), it is unpatriotic for lawmakers to ignore failure of 27 states governments to pay salaries of workers on minimum wage of Ni8, 0०o per month. On record, Sekoni posits further, Nigerian lawmakers are the most highly paid lawmakers on the globe. They obtain, among other perquisites, wardrobe allowance; housekeeper's allowance, driver's allowance, furniture and even constituency allowance to perform executive functions while working part-time on legislative duties for which they were elected.

It is argued that immunity from prosecution is subject to abuses, just as every other law or rule is subject to abuse and adulteration by persons with such disposition to manipulate and corrupt laws and rules for their personal benefit, instead of public benefit. It is the case, therefore, that a governor or president, desirous of subverting public interests and public good for evil and personal gain, could engage in actions that serve personal or parochial interests, which of course amounts to perversions of public and national interest (Tajudeen, 20I3:I9I). In spite of its good intentions, the application of the constitutional provision on immunity for certain categories of elected public officers in Nigeria arguably has more negative than positive implications for democracy and democratic consolidation. It is particularly identified with lack of transparency, embezzlement, lack of accountability and other forms of abuse of power that detract from the beauty and essence of democracy.

The implications of the above for democratic consolidation in Nigeria are quite threatening. That a sitting governor or president cannot be prosecuted for crimes committed against the state simply puts such individuals above the law. It would be a means of breeding criminals in power (Olaoye, 2012:I00).The utility of the executive immunity contained in the Nigerian constitution was called to question during the tenure of Nuhu Ribadu as Chairman of the Economic and Financial Crimes Commission (EFCC) when he was reported to have said he had concluded investigations on about 24 serving governors who would be arrested on the expiration of their term in office on the $28^{\text {th }}$ of May, 2007, on alleged economic and financial crimes. This opened a torrent of attacks on the immunity clause in the 1999 Constitution with some arguments to the contrary however (Arishe, 2010:296). As clearly observed in the Guardian Editorial (2007): 
Hiding behind the fortress proffered by the immunity clause, so many of such officials, only a handful of whom have now been arrested and are being tried, allegedly perpetrated barefaced thefts and acts of money laundering. At the end of the day, so many of them became multi-billionaires with great financial and fixed asset investments in and outside this country. In the event, most of the ex-governors reportedly left empty treasuries for their successors, with scant traces of accomplished developmental projects to show for their huge spending.

Allegations of bare-faced looting of the nation's common patrimony, is done under the protection of the 'immunity clause' as it is popularly called. Even when it is very obvious to the governed that their collective resources are being mindlessly squandered by the very people that are custodians of their resources, there is very little or nothing that can be done. Obviously, elected leaders have found a perfect shield in section 308 of the constitution to commit all manner of atrocities against their people, public affairs analysts say. They say apart from contract inflation and receiving of kick-backs, some of the formulae perfected by many governors to steal their states' treasury dry are security votes and ecological funds, which no one can question them about. Security vote is an unconstitutional allocation of money to governors, especially, to, ostensibly, enable them 'secure' their states. But, it is axiomatic that insecurity is Nigeria's "chiefest enemy", to quote William Shakespeare (Omoike, 20I5). Even the application of the concept of plea bargain originally meant to save time and enhance effectiveness of the judiciary has been abused. As rightly observed by Daramola (2013):

The problem is not with plea bargaining but with the way it has been used to shield high-profile criminals from the full consequences of their actions. The rationale for plea bargaining is to save time but that instrument has been used injudiciously in Nigeria. It is giving the wrong impression to members of the public that once you steal billions of naira, you can escape justice and the full weight of the law by doing plea bargaining.

The application of the immunity clause in the 1999 Constitution particularly in the Fourth Republic, has elicited varying responses from groups, institutions and individual members of the public. These responses have varied from the moderate to the radical. The National Judicial Commission (NJC) made a recommendation to the National Assembly Committee on the Review of the I999 Constitution that the clause be amended to confer immunity on concerned political office-holders on civil matters only, and not 
on criminal matters, as a way of mitigating its negative outcomes (Olaoye, 2012:97).

In the process of amending the Constitution, the House of Representatives once passed 85 new clauses to the 1999 Constitution (as amended), among which was the rejection of immunity for the President and state governors facing criminal charges. According to the report on the immunity clause, 225 constituencies voted for Section 308 to be amended to the effect that the President, vice president, governors and deputy governors be covered by immunity in civil proceedings alone while in office. About I32 opposed the removal of the clause. Three others did not vote.

The section does not protect any sitting member of the National Assembly from facing criminal or civil trial. The report also showed that majority of those who took part in the exercise rejected the blanket immunity conferred on the President, Vice President, governors and deputy governors in the I999 Constitution. Those who believe the clause should be removed cite what they call the high level of corruption since the return to democracy about 16 years ago. It has prevented Nigerians from benefiting from the dividends of democracy. To them, the removal of immunity will prevent the president, vice president, governors and deputy governors from acts that would undermine their office and the Constitution (Emakpe, 2013).

It is an open fact that, in spite of the establishment of anti-corruption agencies and their seeming commitment to fight the social menace, corrupt practices grossly remain an albatross to the nations' development efforts. Corruption and white-collar crimes are widespread at every level. While the Economic and Financial Crime Commission (EFCC) was designed to deal with fraud and other economic crimes, the Independent Corrupt Practices Commission (ICPC), on its part, was set up to deal with corruption, in the public service and by operation also has the power to deal with private persons who come in contact, or aid, or facilitate these corrupt practices.

Even the discovery of large-scale fraud committed by a 'powerful man' is never a guarantee that sanctions will follow. The individual, if well-connected, can often be provided an escape route or what is commonly referred to as a 'soft landing' or 'political solution' in Nigeria. The process typically involves some form of subterranean negotiations or lobbying, spearheaded by 'concerned friends' or 'elders', usually made up of traditional rulers and leading politicians from the community of the accused (Adekoye 2005; The Punch, 7 April 2005 cited in Enweremadu, 2012:105).

The country's elite has learned how to use the complicated legal system, its drawn-out legal processes and overburdened courts to develop 
successful defenses against accusations of corruption or crime. Despite structures introduced to curb it, corruption continues to thrive in Nigeria because the policies and measures were not backed with the necessary political will and sincerity. They are spontaneous mechanisms that often lose steam after attempting to curb deep - rooted or pervasive corruption (Nna and Jacob, 20I2:I23). Put differently, there is a huge disconnect between the state and the people. There is a wide gulf between the rich and the poor. Rights and privileges are disbursed not on equal terms but on how deep the pocket is. The law may be an ass but it knows where to apply the brakes: while the goat thief gets maximum sentence with hard labour, the billion dollar thieves often negotiate their way to their loot (Odunuga, 2012).

Thus, an atmosphere of impunity encourages venality. The growth in the culture of impunity in public life in the last sixteen years or more must have induced the recklessness of thieves in public service, to the extent that the most recurrent topic among citizens today is corruption of men and women in power (Sekoni, 20I6:I4). It is therefore, easy to understand why the public sector is characterized by pension crisis, arrears of salaries of civil servants, huge debts to government contractors and suppliers of goods and services, a boom and burst cycle of revenue and expenditure, misallocation and excessive mismanagement of resources, etc. (Gashinbaki, n.d:3).

\section{The Vulnerable Poor as Scapegoats}

As earlier observed, the Immunity clause in the Nigerian constitution was originally designed to protect government officials in the discharge of their legitimate function. But alas, it has been turned upside down and now used to protect criminals in government. While several past governors facing corruption charges have yet to be convicted, former presidents never get to face the law, even for a day (The Leader, 2015). Yet, while the Nigerian courts mockingly and seemingly ruthlessly deal with the poor, the rich are patronisingly pampered and most times, evade justice.

Though the Nigerian constitution guarantees justice and equality for all citizens, a lot of people, especially the poor and vulnerable, are still unable to get access to justice in the country. While the poor get rotten in prison for years while awaiting trial, soft landing mechanism is devised for the rich - just to return looted money and go home. Meanwhile, the issue has thrown up mixed feelings among Nigerians who have argued for and against any form of soft landing for looters returning money. Observers, 
however, describe plea bargain and soft landing as the same, saying none of them has a place in Nigerian constitution.

In countries where corruption is pervasive in the administration of justice, the implementation of a country's laws as well as efforts to reform them are impeded by corrupt judges, lawyers, prosecutors, police officers, investigators and auditors. Falana (2013) submits that "a criminal justice system which railroads the poor to jail and excludes the rich from prosecution cannot last for too long. It is observable that public officers and rich private individuals are above the law. Such practices compromise the right to equality before the law and the right to a fair trial. They especially undermine the poor's access to justice, because they cannot afford to offer or promise bribes". Importantly, corruption contributes to a culture of impunity, since illegal actions are not consistently punished and laws are not consistently upheld. Indeed, more often, many of the wealthy suspects get perpetual injunctions from court restraining the anti-corruption agencies from probing graft allegations levelled against them.

Some newspaper headlines compiled by this author (See the Table below) confirm that the poor are often jailed for little offences while the rich or influential public office holders continue to perpetrate impunity after lenient punishments (returning a fraction of the stolen money, usually in billions of naira these days) via plea bargain. This approach, no doubt, makes a mockery of Nigeria's judicial system. Even under the present administration, reprieve seems to be coming the way of treasury looters who voluntarily return those monies to the nation's coffers as the Federal Government is considering some form of 'soft landing' for them. Citing its interview with the Presidential Spokesman, Femi Adesina, BusinessDay (2015) notes that that "those who make deliberate efforts to return monies would have some form of concession, although he could not confirm what Buhari is specifically planning for this set of treasury looters".

Since news of the Dasukigate scandal broke, some angry members of the public have been crying for blood like spectators at the old Roman gladiatorial shows. This public vibe must have been felt by the Federal Government, prompting it to state earlier that it would not consider an option of plea bargain for treasury looters and their cronies. The Minister of Justice and Attorney-General of the Federation, Abubakar Malami, had in December 20I5, said that the government would not "allow criminal cases to be compromised" and that his office would "not advocate plea bargain for anyone" (The Punch, 20I6). Confirming that the Federal Government may have changed its stance on the issue, the Chairman of the Presidential Anti-corruption 
Advisory Committee, Prof. Itse Sagay, in a statement, said some people had started returning looted funds and that there would likely be a 'soft landing' for them (ibid).

The application of plea bargaining, according to Mudasiru (20I5) in several countries such as Canada, Malaysia, United States of America, Spain, South Africa, Zambia, India, Central African Republic and a host of others come with legal frameworks which originated from the constitutions of these countries and in most cases, it is being done away with. For instance, in India, plea bargaining has been rejected in several cases at the level of the country's Supreme Courts. Also in Malaysia, it is reported that the legal system in Malaysia does not recognize the concept of plea bargaining. Nevertheless, there are indications of negotiations in the criminal procedures of the country.

This has since been jettisoned, as new legal provisions in the country did not allow the use of the concept in its criminal justice system. Even in the USA, where the practice had been in use since $18^{\text {th }}$ Century, it is no longer fashionable to apply the concept of plea bargaining in the criminal proceedings in the country. In South Africa, several Committees were raised to investigate the issue of plea bargaining before it was entrenched in the Constitution of the country. This is not without modifications and procedure on the sentencing (South African Law Commission, 200I cited in ibid).

\section{The Vulnerable Poor}

Bus Driver Sentenced to Death for Stealing
N68, 000, Vanguard, April 22, 2016

Access to justice: Only the Rich Benefit, the Poor Suffer,
Newswatch Times, May 13, 2014

\section{The Influential Rich}

Nigerian Official Convicted For Stealing N 32.8 Billion Gets Two Years in Jail, Or Option Of N750,000 Fine,

SaharaReporters, January 23, 2013

Court Sentences ex-NIMASA Boss, Omatseye to 5-year Imprisonment Over a N1.5bn Contract Scam, Vanguard, May 20, 2016

Man to Die by Hanging Over N14,570

Robbery, Vanguard, December 4, 2015

Man Jailed for Stealing N3,060 in Abuja Daily Post, May 25, 2016
Cecilia Ibru Gets Six Months in Jail Ion a three count charge of negligence, reckless grant of credit facilities running into billions of dollars) Vanguard, October 9, 2010, Nigerian Elites Forum, October 9, 2010

N1.4bn Fraud: Court Sentences Ex-Kogi Lawmaker to 154-year Jail, (two years on each of the 77 counts to run concurrently), Premium Times, April 25, 2016 
18-yr-old Man Sentenced to 4 Years Imprisonment for Stealing N28 Thousand, http://pulse.ng/gist/like-seriously-18-yr -old-man-sentenced-to-4-years-imprisonment-for-stealing-n28k-id4474326.html

45 Years for Man who Stole Aregbesola's Phone,

The Nation, April 30, 2013

Two Men Bag 17 Years in Prison for Stealing, Duping with Governor Aregbesola's Cell Phone,

Daily Post, March 1, 2014

Petty Thief: Housemaid Jailed for Stealing Mistress Pants -

Nigeria News, January 17, 2016

419: UNILAG Student Bags 19-Year Jail Term,

http://nigeriavillagesquare.com/forum/ archive/index.php/t-30667.html

\section{Convicted Internet Fraudster To Spend 10}

Years In Jail,

http://www.naijaloaded.com.ng/2016/06/17/ convicted-internet-fraudster-spend-10-years-jail/, June 17, 2016

\section{Nigerian Secondary School Student To} Die By Hanging For Stealing Phone And Recharge Cards, http://www.informationng.com/2013/11/ student-to-die-by-hanging.html
Nigerian Ex-Police Chief Sentenced to Six Months in Prison, larrested and put on trial for about N5.7billion official corruption), BBC News, November 22, 2005

Former Governor, DSP Alamieyeseigha Pleads Guilty-Jailed 2 Years!, (He was detained in London on charges of money laundering in September 2005, Metropolitan police found about $€ 1 \mathrm{~m}$ in cash in his London home. Later they found a total of $€ 1.8 \mathrm{~m}(\$ 3.2 \mathrm{~m})$ in cash and bank accounts. He was found to own real estate in London worth an alleged $€ 10$ million) SaharaReporters, July 25, 2007

\section{Money Laundering: Michael Igbinedion} Gets Six Year Jail Term- an Option of N3 Million Fine. lover alleged laundering of N25 billion fund belonging to Edo state government),

SaharaReporters, April 30, 2015

\section{Enugu High Court Convicts Lucky Igbine-} dion, Fines him N3.5 million I Having being accused of looting about $\mathrm{N} 4.4$ billion) Daily Sun, December 19, 2008

Bode George: 2 Years Jail-Term Scandalous for Offence Committed. (Inflation of Contracts to the Tune of N84 billion with five other NPA Board Members)

Vanguard, November 1, 2009

Ibori: Entangled Victory in Corruption Trial (freed of the initial 170-count charge essentially of money laundering against himl.

Daily Trust, December 26, 2009

James Ibori: “Innocent” in Nigeria, Guilty

Abroad, National Mirror, March 4, 2012

Nigeria: Odili, former Gov. of Rivers States, Secures 'Perpetual Injunction' Against Arrest, (The anti-corruption body has been investigating his finances and has said he is suspected of embezzlement, money laundering and gross abuse of office), SaharaReporters, March 12, 2008 
Oluremi Olayinka Sentenced to 266 Years Imprisonment for Stealing N8m, The Guardian, April 23, 2015
Disgraced Fmr Speaker Salisu Buhari of "Toronto University Forged Certificate" Now in UNN Governing Council, http:// www.9jabook.com/forum/topics/disgracedfmr-speaker-salisu-buhari-of-toronto-university-forged-

Source: Compiled by the Author

From the table above, it is glaring that the Nigerian reality remains widely poisoned by a climate of arbitrariness, corruption and impunity. For instance, when the EFCC brought I70 criminal counts against former governor James Ibori, a judge sitting in Ibori's home state threw out every single count - including evidence that Ibori paid EFCC officials \$I5 million in an attempt to influence the outcome of the investigation. The judge ruled that the EFCC had failed to produce a written statement by the man who allegedly conveyed the bribe corroborating their version of events and that the prosecution's proffered eyewitness testimony would inevitably amount to "worthless hearsay evidence" (Human Rights watch, 20II).

Ibori was eventually jailed on the same criminal charges in the United Kingdom. Many high profile cases in Nigeria have suffered similar fate in the past. It has always been justice for the affluent few and cruel judgement for the downtrodden. Yet, the political leadership, over decades, has failed to address these fundamental challenges just as the gap between the governing elite and the masses continue to expand. In the words of El-Rufai (20I3), Nigerian masses have been successfully divided by the elites along ethnic, religious and regional lines. This chasm has been so deep and successful that it is impossible to have any sensible discussion with most people in Nigeria about any issue without the intervention of these evil lenses. He observes further:

In Nigeria, our elites have forgotten that, and not only is the gap between the classes growing wider, it seems that the country now has two economies - one for the majority that have to scrounge just to put food on the table, and an exclusive economy for the less than I\% of the population that comprise public servants and their hangers on who live in a different Nigeria - of private jets, exclusive estates, international schools, German healthcare at public expense, dedicated water supply systems, private security guards and imported champagne. 
Occupants of public offices in Nigeria, see their tenure as an avenue for personal aggrandizement and as a means of getting their own share of the national cake. Thus, they steal from the public treasury with reckless abandon (Human Development Initiatives, 2014:6). This trend threatens the integrity of the judiciary and the protection of individual rights in the country. For the Nigerian political (ruling) class, the state is nothing but an instrument of accumulation. This informs its centrality as the locus of struggle for material resources for personal advancement and class security (Gilbert and Barigbon 20I5:II7). Since the formation of States in human socio-cultural development, all other forms of power have almost always been subordinated to political power and are controlled by it.

This explains the attractiveness of political power and why, in a morally decadent society like Nigeria, politicians are willing to acquire state power through any means (Anele, 2010). The character of the State in Nigeria rules out a politics of moderation and mandates a politics of lawlessness and extremism because the very nature of the State and the perquisites of office make the capture of State power irresistibly attractive. As noted by Ake (2000:9I) where attempts are made to seek development, policies tend to be hampered by social and political contradictions such as the divorce of public policy from social needs. The lawless struggle for power by those who control the state against other interests leads to endemic political instability which has been highly detrimental to economic development.

\section{Conclusion}

It is established in this essay that the rule of law, as a basis for democratic governance, includes not only the supremacy of the law, but a democratic basis for law that makes the law legitimate. That basis, according to USAID (20I0:7), is that laws represent the collective will. In societies where the rule of law is observed, virtually all citizens obey laws, even when doing so contravenes their personal interests. This willingness is not based solely on the threat of sanctions, it also arises from the citizens' recognition that laws are arrived at in a manner set out in a constitutional order and subject to social input.

This essay subscribes to the fact that an independent and impartial administration of justice contributes to strengthen constitutional norms and rule of law in the society. An efficient judiciary contributes towards strengthening the state institutions and promoting good governance. This 
is possible only when state organs and institutions perform functions by remaining within their allotted spheres. Musa (2013) contends that no combat against crime, corruption and other social vices plaguing the country can either be credible or complete unless at the end of the day there is in place an independent, effective, and robust judicial system to count on. A properly administered judicial system capable of guaranteeing individual rights and freedoms, protecting victims from the arbitrary exercise of power, and punishing criminal offenders, is an essential catalyst for good governance and uplifting of the socio-economic wellbeing of Nigeria and her citizens.

\section{REFERENCES}

Ake, Claude (2000) The Feasibility of Democracy in Africa, Senegal, CODESRIA

Anele, Douglass (20I0) Politics and Morality in Nigeria: A Critical Analysis (3), Vanguard, November 28

Arishe, G. Omo (2010) Reconsidering Executive Immunity under the Nigerian Constitution, (2007-2010) Nigerian Current Law Review

Arthur-Worrey, (n.d) Curtailing the Culture of Impunity in Our National Life (Part I)Retrieved September I8, 2016 from: http://gavelinternational.org/curtailing-culture-impunity-national-life-part-I/\#sthash. 4CHITLyd.dpuf

BusinessDay, December I6, 2015

CODESRIA (2003) The African Power Elite: Identity, Domination and Accumulation, Retrieved September I8, 2016 from: www.codesria. org/spip.php?article59

Daily Mail (20I2) Former Croatian Prime Minister Jailed for Ten Years in Corruption Crackdown ahead of Country's EU Membership Next Year, November 20

Daramola, Olu Lucas (2013) Judicial Delays: Greatest Challenge of Nigeria's Justice Administration, Newswatch, July 23

Duru, O. W. (20I2) The Relationship Between The Elite Theory of Politics and The Concept of Liberal Democracy, Retrieved September I8, 2016 from: http://ssrn.com/abstract=2I47363 or http://dx.doi. org/10.2139/ssrn.2147363

Eglash, Ruth (2015) Former Israeli prime minister sentenced to 8 months in prison, Washington Post, May 25 
Emakpe, Gowon (2013) Who Deserves Immunity: President, Governors or NASS Members?, Newswatch Times, August 9

Enweremadu, David (20I2) Anti-Corruption Campaign in Nigeria (I9992007) The Politics of a Failed Reform, African Studies Centre (ASC) Institut Français de Recherche en Afrique (IFRA) West African Politics and Society Series, Vol. I

Falana, Femi (2007) Ethics and Governance, the Rule of Law and Anti-Corruption: A Nigerian Dilemma, Retrieved May I3, 2013 from: http://saharareporters.com/2007/I2/08/ethics-and-governance-rule-law-and-anti-corruption-nigerian-dilemma-femi-falana

Falana, Femi (2013) Pardon, Amnesty and Impunity in Nigeria, Being the Paper Delivered at the Training of the Stakeholders and Implementers of the Stop Impunity organised by Stop Impunity Now Campaign from May 2-3, 2013 in Lagos, The Punch, May 6

Falana, Femi (2016) There is no absolute immunity in Nigeria's Constitution, Retrieved September I8, 2016 from:http://www.nigeriannation.com/nigerian-daily-news/there-is-no-absolute-immunity-in-nigerias-constitution-says-falana.aspx

Frase, Christian (20II) French ex-President Jacques Chirac guilty of corruption, BBC News, December I5

Gashinbaki, Iliyasu Buba (n.d) Anti-Corruption: An Evaluation of Strategies, Legislations and Systems in Nigeria, Retrieved September I8, 20I5 from:http://www.dcp.com.ng/files/Anti-corruption\%20 -\%20An\%2oevaluation\%2oof\%2ostrategies,\%2olegislations\%20 and\%20systems\%20in\%2oNigeria.pdf

Gilbert, Lysias Dodd and Barigbon, Christopher Barisi (2015)The Politics of Poverty in Democratic Participation: Nigeria in Perspective, Developing Country Studies, Vol.5, No.18, 20I5

Gumede, W.M (20I0) “Toast Masters”, Focus on Africa, October-December, $2 \mathrm{I}(4): 22-23$

Hassan, Shaukat (2004) Corruption and the Development Challenge, Journal of Development Policy and Practice, Vol I, Number I

Ihonvbere JO (I999) Federalism, Power Sharing and the Politics of Redistribution in Nigeria: A paper presented at the International Conference at Sintra new Lisbon Purtugal, September, 2I-25

Konrad-Adenauer-Stiftung (20II) Concepts And Principles of Democratic Governance and Accountability: A G u i d e F or P e e r E d u ca t o r s, Published under the project: 'Action for Strengthening Good 
Governance and Accountability in Uganda' by the Uganda Office of the KonradAdenauer-Stiftung

Los Angeles Times (2016) Ex-state Sen. Leland Yee gets 5 years in prison in corruption case, Feb 24, Retrieved June 12, 2016 from:http://www. latimes.com/local/lanow/la-me-ln-yee-sentence-20160223-story. html

Mudasiru, Surajudeen Oladosu (2015) Democracy, Plea Bargaining and the Politics of Anti-Corruption Campaign in Nigeria (I999-2008), African Journal of Political Science and International Relations, Vol.9(9), pp. 335-348, September 2015

Musa, Charles, (20I3) Judicial Overhaul Urgently Needed In Nigeria, Premium Times, July II, 2013

Nna, N.J and Jacob, O.A (20I2) The Institutional Approach to Anti-Graft Crusade: The Case of Independent Corrupt Practices Commission in Nigeria, African Journal of Social Sciences, Volume 2 Number I(20I2), pp. II6-I29

Odunuga, Yomi (2012) Democracy and a Nation's Dismal Rights Record, The Nation, May I9

Ogbeidi, M.M (20I2) Political Leadership and Corruption in Nigeria Since I960: A Socio-economic Analysis, Journal of Nigeria Studies, Vol. I, Number 2, Fall 2012l 2012

Ogbodo, Gozie (20II) The Immunity Clause Under the I999 Constitution and the Anti-Corruption Crusade - A Case of Strange Bed-Fellows? NIALS Journal of Law and Development, Vol. No. I 20II

Ogunye, Jiti (2016) Forgery of Senate Standing Orders: The Difference Between Immunity and Impunity, Premium Times, June 2I

Olaoye, Olugbenga (20I2) The Significance of the Immunity Clause for Democratic Consolidation In Nigeria, African Journal of Criminology and Justice Studies: AJCJS, Vol.6, \#sI \&2

Omoike, Benjamin (20I4) Legislative Immunity: Testing sensibility of Nigerians? Newswatch, January 26

Sekoni, Ropo (2016) Senate's Constitution: Are We All Frogs in Temperate Water? The Nation, June 26

Tajudeen, Ibraheem Ojo (2013) Executive Immunity in Nigeria: Putting Off Old Garments, Journal of Politics and Law; Vol. 6, No. 3 
The Leader News Online (20I5) Immunity for Impunity: Time for amendment!, Retrieved September I8, 2016 from:http://theleaderassumpta.com/20I5/IO/II/immunity-for-impunity-time-for-amendment/

The Punch Editorial (20I6) Controversy Over Plea-Bargaining, Soft Landing for Looters, February 27

USAID (20I0) Guide To Rule of Law Country Analysis: The Rule of Law Strategic Framework, A Guide for USAID Democracy and Governance Officers, USAID's Office of Democracy and Governance, Rule of Law Division

Weingast, Barry R. (2008) Why Developing Countries Prove So Resistant to the Rule of Law, Department of Political Science, Stanford University

\begin{abstract}
In Nigeria today, some aspects of our constitution give immunity clause to serving political office holders which prevents them from being prosecuted in a court of law over alleged offences against the state committed while in office until after their tenure. This immunity clause has led to an alarming rate of executive lawlessness and official corruption in the corridors of power by Nigerian political ruling class as they continually abuse these privileges with high sense of impunity. Their associates and friends also enjoy unofficial immunity as they recklessly flaunt existing laws. This, many a times, goes without any form of punishment to serve as deterrent to other potential offenders. It often precipitates more abuse in the polity. Yet, while the Nigerian courts mockingly and seemingly ruthlessly deal with the poor, the rich are patronisingly pampered and most times, evade justice. Though the Nigerian constitution guarantees justice and equality for all citizens, a lot of people, especially the poor and vulnerable, are still unable to get access to justice in the country. While the poor get rotten in prison for many years in the course of trial, soft landing mechanism is devised for the rich - just to return a fraction of the looted money and go home. This study therefore, interrogates the content and context of elite immunity and its attendant culture of impunity that permeates the political environment in Nigeria.
\end{abstract}

\title{
Key Words
}

Immunity; Impunity; Constitution; Prosecution; Corruption. 